\title{
UNDERSTANDING FINANCIAL CRISIS: A THEORETICAL ANALYSIS
}

\section{P.K. Sudarsan*}

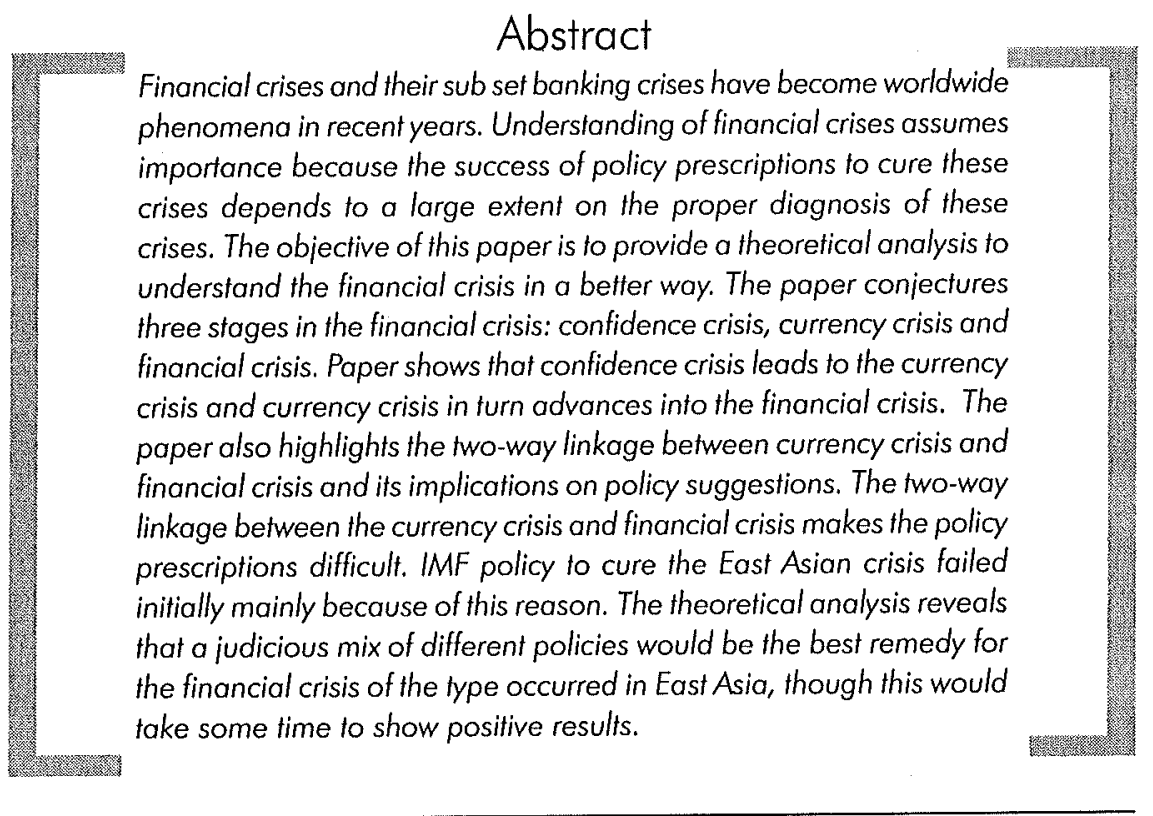

* Lecturer in Economics in Goa University, Goa. E-mail: sudha@unigoa.ernet.in and sudhapazhu@yahoo.com 


\section{Introduction}

Financial system facilitates the movement of funds from economic agents who do not have productive investment opportunities to those who have investment opportunities. Unless the financial system does this job effectively, the economy will not function efficiently and economic growth will be adversely affected. Crises in the financial system that has occurred recently have demonstrated their adverse effect on the health of the economy. The damage these crises impose on developing countries seems very serious. The financial crises in Mexico and East Asia are examples for that.

Financial crises and their subset, banking crises, have become worldwide phenomena in recent years (Mishkin, 1997). The currency and banking crises have occurred several times in different countries during 1980's and 90's. Several Latin American countries have experienced these crises during the last two decades. Chile in 1982, Argentina in 1982 and 1995, Venezuela in 1994 and Mexico in 1994-95 are some of the examples. Finland, Sweden and Norway have experienced it in 1990 's. The currency and banking crises have shattered Southeast Asia recently. East Asian crisis is the most devastating crisis in recent years. The gravity of the crisis may be understood from words of Krugman (1998), "If Asia does not act quickly, we would be looking at a true depression scenario - the kind of slump that 60 years ago devastated societies, destabilized governments and eventually led to war". The financial crisis in East Asia has even slowed down the world's economic growth. The financial crisis experienced in Argentina few months back reveals that the dragon of financial crisis can raise its head any time anywhere in the world.

In this context, understanding of financial crisis assumes greater significance. The success of the policy prescriptions depends to large extent on the proper diagnosis of the crisis. Proper understanding of the crisis would also help in taking precautionary measures well in advance.

The broad objective of present paper is to understand the financial crisis by identifying various factors which cause the crisis at different stages. This paper conjectures that the financial crisis develops through different stages, namely, the confidence crisis, currency crisis and financial crisis. The theoretical analysis to understand the financial crisis is attempted here with special focus on East Asian Crisis.

\section{Theoretical Background}

The literature available on currency crises may be classified into three categories. First generation, second generation and third generation models. The first generation 
models were applied to explain the currency crisis of developing countries like Mexico (1973-82 crisis) and Argentina (1978-81 crisis). The root cause of these crises was expansionary domestic policies. Krugman's (1976) classical model shows that under fixed exchange rate system, domestic credit expansion leads to loss of international reserves and ultimately to speculative attack on currency. This attack immediately depletes the reserves and forces the authorities to abandon the fixed exchange rate.

Second generation models were applied to crises where speculative attacks are the major cause of crisis and these attacks are unrelated to the market fundamentals. These models have taken into account the bandwagon effects. According to second generation models speculative attacks and the consequent currency crises are not due to excessive money growth or other misaligned fundamentals, but to selffulfilling panics. Theoretical model advanced by Obstfeld, $M$ (1996) based his theory to self fulfilling prophecies as a reason for the crisis. The model advocates that the economic crisis might appear without a change in fundamentals. The economy may be in equilibrium consistent with a fixed exchange rate, but a sudden worsening of expectations may lead to a sudden collapse of the existing regime thereby validating the agent's expectations, i.e., self fulfilling prophecies. Theory by Daimond and Dybvig (1983) attributes the bank panic and bank runs to changes in expectations. Changes in expectations depends on almost anything. A panic is an adverse equilibrium outcome in which short-term creditors suddenly withdraw their loans from a solvent borrower. Panic occurs when three conditions exist: i) short term debt exceeds short term assets, ii) no single market creditor is large enough to supply credits, iii) there is no lender of last resort.

The third generation models emphasise on the link between banking crises and currency crisis (Gandolfo, 2001). But the link is not clearly given. The chain of causation might run either way. Problem of financial crisis give rise to the currency crisis and collapse. On the opposite side, balance of payments problem might cause banking crises. Finally there is possibility that currency and financial crises might have common causes.

\section{Different Stages of the Financial Crisis}

This section presents a theoretical outline of different stages in the evolution of financial crisis with special reference to East Asian Crisis. The objective behind this kind of analysis is to identify the factors which cause the crisis in each stage and to see how one type of crisis advances into the other. 


\section{a. Confidence Crisis}

Thailand, Malaysia, Indonesia, Singapore, efc. achieved remarkable economic growth and received worldwide attention. The growth of these economies was so rapid that they were called as miracle economies. Thai economy was one of the favourites of investors. Foreign companies were flooding Thai economy with loans. All fundamentals in the Thai economy seemed very strong. All on a sudden investors' view of Thailand changed and speculators started targeting the Baht, the Thai currency. This has resulted in a confidence crisis. The factors contributed to the confidence crisis in East Asia are given in Figure-l.

FIGURE-I : CONFIDENCE CRISIS

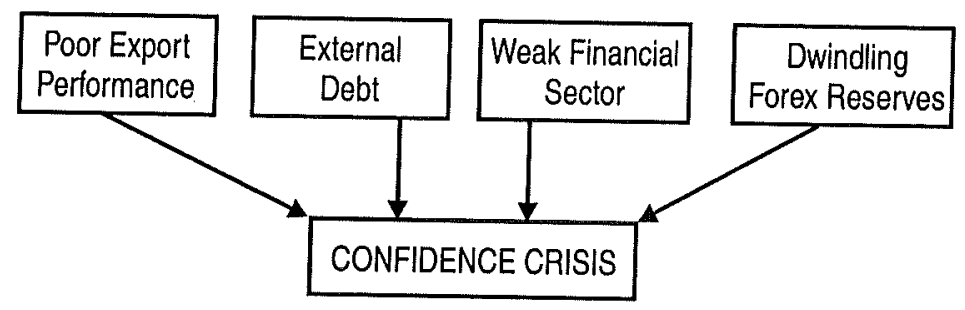

The major source of confidence crisis was poor export performance (Singh, 1998) and huge external debt. Thailand was an export-oriented economy. Domestic economic growth depended to a large extent on export earnings. The export earnings have been stagnated mainly due to the competition from the neighboring countries like China, Vietnam, Indonesia, etc. The overvalued exchange rates have reduced the competitive edge of the Thai exports. Low productivity and increasing labour costs also contributed towards poor export performance. Huge external debt and its structure helped very much in building up confidence crisis. By the end of 1996, the external debt of Thailand had reached about $\$ 70$ billion. Out of that 40 percent was short term debts. Volatility of short term debts made Thailand vulnerable to crisis. The majority of debts were denominated in dollars causing concern for investors in case of the exchange rate falls.

The weak financial system and pegged exchange rate system were the other factors responsible for the confidence crisis. Financial system was corrupt in Thailand. Most of the bank managers had political interest. Flushed with funds, they were not following the norms and procedures of banking properly. Most of the branches had large percentage of non-performing assets (NPAs). All these have reduced investor confidence. Perhaps the most important reason for confidence crisis was 
the pegged exchange system that was in existence in Thailand. Thailand had to use its limited forex reserves to defend the pegged exchange rate system. The forex reserves dwindled to a low level causing concern to the investors.

\section{b. Currency Crisis}

The currency crisis is defined as a situation in which an attack on the currency leads to a sharp depreciation of currency, a large decline in international reserves, or a combination of the two (Kaminsky, et al, 1998). The currency crisis is caused mainly by the government's failure to defend the pegged exchange rate system. In East Asia, the confidence crisis made the way for currency crisis. It was the speculative attack on currency, which ultimately led to the currency crisis. The structure of currency crisis is given in Figure-ll.

\section{FIGURE-II: CURRENCY CRISIS}

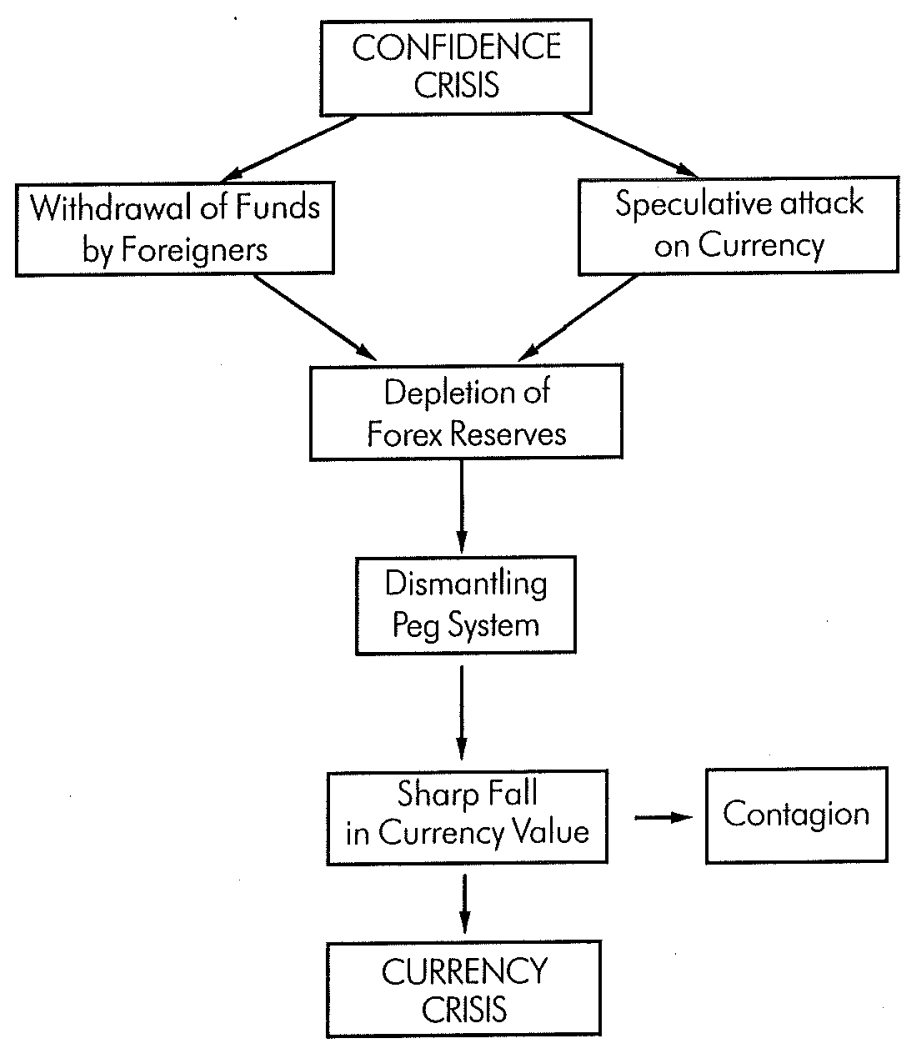


In 1996 capital was flowing into emerging Asia at the rate of almost $\$ 100$ billion a year; by the second half of 1997 it was flowing out at almost the same rate (Krugman, 1998). The Thai Baht was tested by speculative attacks in the late 1996 and in the first half of 1997 Bank of Thailand spent a large portion of the nation's forex reserves to defend the exchange rate system through direct sale of foreign currency swaps. However, speculative attacks continued and have become successful in July, 1997 resulting in a currency crisis. Government couldn't defend its currency as the forex reserves got depleted. Consequently, government had to abandon the 13-year-old peg system. When Baht was floated, it inevitably sunk. Prior to the float, Bank of Thailand acted as lender of last resort and there was no significant risk premium. By float, Bank of Thailand decided that it would not act as a lender of last resort and the risk premium went sky high leading to sharp fall in the value of domestic currency. It is a case of confidence crisis leading to currency crisis. Contagion has helped to spread currency crisis to other regions of Asia.

\section{c. Financial Crisis}

The financial crisis is a situation in which financial system ceases up abruptly and almost stops functioning (Mishkin F, 1997). The East Asian crisis is more of a financial crisis than any other forms of crisis. It appears that currency crisis has developed into financial crisis and that devastated the economies of Southeast Asia. There are many factors which have contributed to the financial crisis in East Asia:

i) Short-term foreign currency borrowings were used to finance domestic long term investments in property, hotels and tourism.

ii) Credit to the private sector was expanding very rapidly. Banks have resorted to borrowing abroad to finance these credits.

iii) There was maturity mismatch in banks portfolio as they were borrowing short term offshore and lending long term onshore.

iv) Banks exposed themselves to the risk of currency depreciation by borrowing in foreign exchange and lending in domestic currency.

v) Banks indulged in indiscriminate lending in dollars denominated loans to borrowers whose earnings were not in foreign exchange. These borrowers faced bankruptcy due to steep depreciation.

The nature and structure of financial crisis is exhibited in Figure-III. The figure shows how the currency crisis has been developed into a financial crisis. The currency crisis involved sharp fall in the value of domestic currency in Thailand. This depreciation of currency caused inflation, both actual and anticipated, causing domestic interest rates to rise. This rise in domestic interest rates led to higher interest payments on short-term debts when it was rolled over. The sudden increase 
in interest payments made it more difficult for the households and firms to service their debts. Moreover, banks became illiquid due to short term nature of their liabilities and long term nature of their assets. This has deteriorated the bank balance sheets making the ground for financial crisis.

FIGURE-III : FINANCIAL. CRISIS

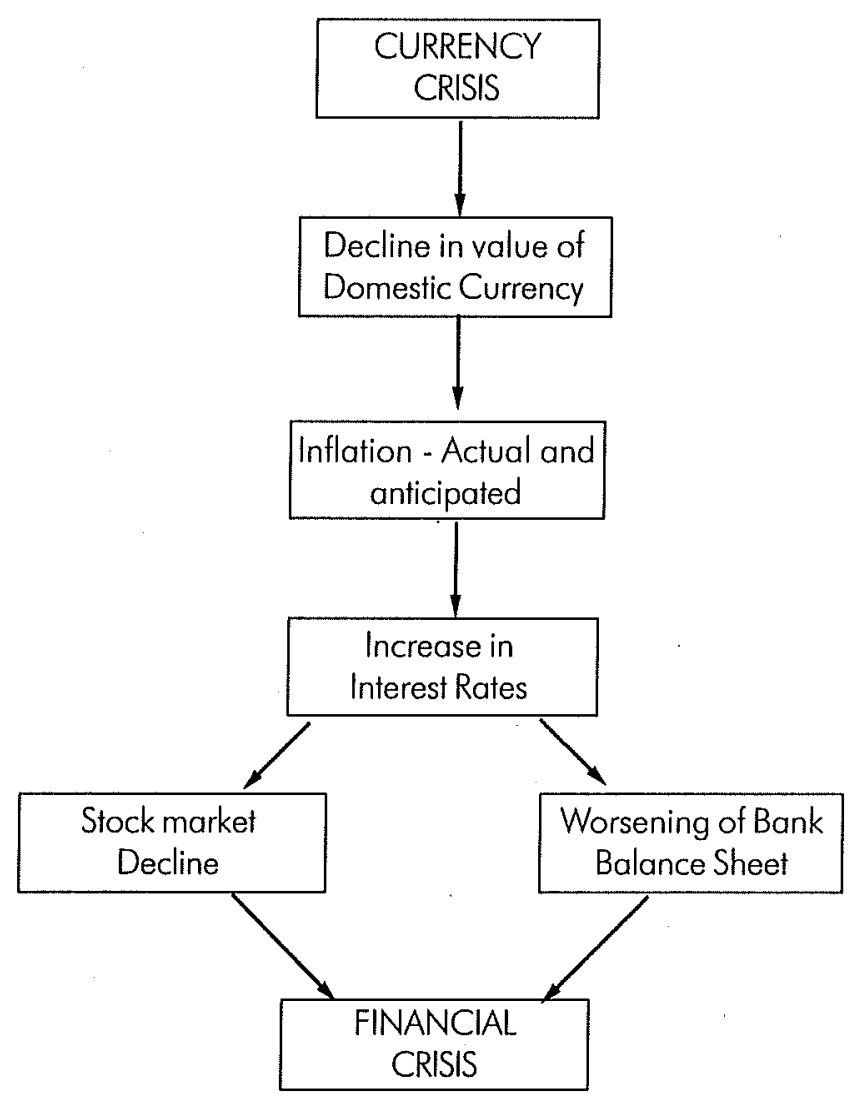

The problems outlined above led to the collapse of banking system causing panic among the depositors. The bank panic has made the depositors to withdraw their funds from the banking system in order to limit their losses, deepening the crisis. The result of the financial crisis is a severe decline in economic activity. Thus what started as an exchange rate crisis (currency crisis) turned into a banking and financial crisis. 
Stock market crashes also typically associated with financial instability. The decline in stock prices in recent years has been a precipitating factor in each country's financial instability (Mishkin, 1997). A stock market crash leads to a large decline in the market value of firm's net worth. In times of financial crisis, interest rates are pushed up to keep the value of currency from falling further. This will adversely affect the stock market. Thus stock markets also play an important role in financial crisis (Rao Banoii, 1998). However, in Asian economies banks played dominant roles compared to stock markets in financial crisis. The stock markets for both the equity and debt have remained relatively a minor source of capital in many Asian economies.

Interest rate plays a crucial role in financial crisis. If market interest rates are going high, there is high chance that banks lend to borrowers with high credit risks because low credit risk borrowers are less likely to borrow at a very high interest rate. Because of the resulting increase in adverse selection, lenders will make only fewer loans leading to a reduction in investment and economic activity. Increase in interest rates can indirectly promote the financial crisis through their effects on firms and household balance sheets. A rise in interest rates leads to a rise in interest payments by the firms and households causing deterioration of their balance sheets. This would reduce lending to those households and firms leading to decline in lending and aggregate economic activity. Eventually, the financial system would stop almost functioning. The same thing happened in East Asia.

\section{Linkages of Different Stages and Policy Implications}

The above analysis shows that the confidence crisis leads to currency crisis and currency crisis advances into financial crisis. It is very important to note that currency crisis and financial crisis may interact and reinforce each other to deepen the crisis. Weak financial system is a major factor causing confidence crisis. The confidence crisis leads to speculative attacks and currency crisis. Therefore, when the financial crisis further weakens the financial system, it, in turn, may cause currency crisis through confidence crisis.

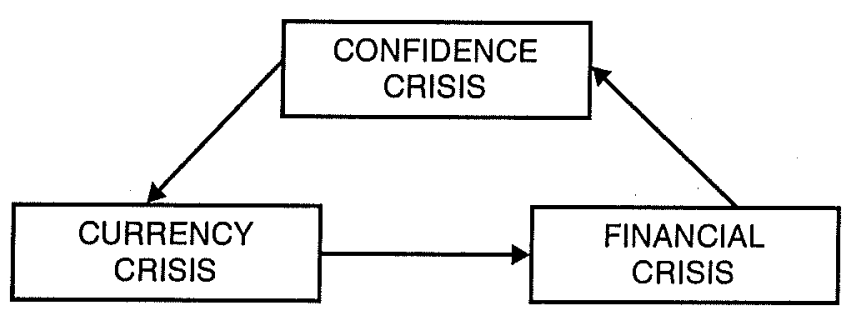


This linkage makes understanding of the crisis more complex. Linkage also makes policy measures difficult. The policies which suggests for curing currency crisis may worsen the financial crisis and policies to check financial crisis may worsen the currency crisis.

In the light of above analysis, it would be interesting to review the policy suggestions made by IMF to cure the financial crisis in East Asia. Since the crisis is caused mainly due to the shaking of confidence of the investors, the policy suggestion should be one, which would help regain the confidence in the economy. The aim of IMF policy in East Asia was to restore investors confidence (Hoeing, 1997). IMF suggested these countries to stabilize their exchange rates by temporarily raising domestic interest rates. IMF programs also included reforms to place their financial system on sound footing. IMF suggested for closing of insolvent financial institutions, recapitalising the weak, strengthening financial regulation, supervision, etc. IMF policy was contractionary in nature. High interest rates actually undermined the profitability of the banks and firms aggravating the downturn. Closing down of financial institutions have increased the prevailing panic, with depositors in other institutions fearing that they would be the next victims. The recapitalisation program also worsened the profitability of the bank. IMF measures have turned reverse.

It is believed that the IMF policy in East Asia has failed mainly because diagnosis of the financial crisis by IMF was not correct. Many criticized IMF prescriptions, which focused on stabilising the currency by raising the interest rates. They were of the opinion that the increase in interest rates helped only to worsen the financial crisis. However, there are reasons to believe that IMF policy prescriptions were not totally wrong. It was the currency crisis, which caused the financial crisis in the early stages of the crisis. The two way linkage was established only at a later stage. As per the theoretical analysis attempted in this paper, there is reason to believe that the linkage of currency crisis to financial crisis was stronger than the reverse linkage. In this context, stabilization policy of IMF which suggested for the increase in interest rates appears to be a correct measure. The austerity measures suggested by IMF to place the financial system on a sound footing are a proof that IMF has understood the problems in the financial sector and perhaps the two way linkage between currency and financial crisis also. IMF could have done nothing much more than that. What IMF tried might have been to control the currency crisis first without further worsening the financial crisis in the short run. Instead of the above policy, had IMF tried to remove financial crisis through lowering of interest rates. Currency value would have fallen steeply worsening the currency crisis and thereby the financial crisis. Therefore, the lowering of interest rates as suggested by critics also would have worsened financial crisis. 


\section{Conclusion}

The financial crisis may be thought of as having different stages: confidence crisis, currency crisis and financial crisis. Confidence crisis leads to currency crisis and which in turn causes the financial crisis. Though it is possible to see the financial crisis in three stages, it is not necessary that it follows the same sequence always. There can be two way linkage between currency crisis and financial crisis. Sometimes, currency crisis may cause the financial crisis and other times financial crisis may cause the currency crisis. However, this two way linkage is likely to take place only at a later stage of the crisis. When both crises have a two way linkage, it is really difficult to find a solution which would remove both the currency and financial crises. In such a situation, policy suggestion for currency crisis, may lead to worsening of financial crisis or policy suggestion for financial crisis may lead to deterioration of currency crisis. The judicious mix of policies, in this situation, assumes importance. The policy makers have to wait patiently to get the good results of the policy. In the short run the policy may become counter-productive. However, in the long run it can show positive results. This is what is happened in East Asia. Available evidence shows that in East Asia currency crisis led to the financial crisis in the beginning and established a two-way linkage at a later stage. IMF policy suggestions, though became counter-productive in the short run, worked satisfactorily in the long run validating the need for the judicious mix of policy to control the financial crises.

\section{References}

1. Daimond, D.W. \& Dybvig, P.H. [1983], Bank runs, Deposit Insurance and Liquidity, Journal of Polifical Economy, Vol. 91(3), pp 401-19.

2. Gondolfo, G. [2001], International Finance and Open Economy Macro-economics, Springer Verlog, Berlin.

3. Hoeing, T.H. [1997], Asian Financial Crisis, Federal Reserve Bank of Kansas Cily Economic Review.

4. Singh, Rakesh [1998], The East Asian Bubble, Indian Management, Vol.37(4), pp 58-63.

5. Kaminsky, G. Lizando, S. \& Reinhart, C. [1998], Leading Indicators of currency crises, IMF Staff Papers, Vol.45(1), pp 1.47.

6. Krugman, Paul, [1998], Saving Asia: It is time to get radical, Fortune, Vol.138(5), pp 33-38.

7. Krugman, Paul [1979], A model of Balance of Payments Crisis, Journal of Money, Credit and Banking, Vol.11(3), pp 311-325.

8. Mishkin, F. [1997], Causes and Propagation of Financial Stability: Lessons for Policy Makers, in Conference Volume, Managing Financial Stability, Federal Reserve Bank of Kansas City.

9. Obstfeld, M. [1996], Models of Currency Crises with Self-Fulfilling Prophecies, European Economic Review, Vol.7, pp 535-552.

10. Rao, Banoii, [1998], East Asian Economies: The Crisis of 1997-98, Economic and Polifical Weekly, Vol.33(23), pp 1397.1416. 